\title{
ORGANIZACYJNE UCZENIE SIĘ JAKO DETERMINANTA ZATRUDNIALNOŚCI PRACOWNIKÓW
}

DOI: 10.33141/po.2020.07.03

Sylwia Wiśniewska, Kamil Wiśniewski

\section{Wprowadzenie}

$\mathrm{E}$ woluujący rynek pracy, niezapewniający powszechnego bezpieczeństwa zatrudnienia, implikuje konieczność zwiększania poziomu swojej zatrudnialności (employability). W dobie wzrostu światowych zasobów wiedzy, które w dużej mierze ulegają szybkiej dezaktualizacji, w celu zachowania lub wzmocnienia swojej zatrudnialności nieodzowne jest permanentne uczenie się. Powstanie i popularyzacja koncepcji organizacyjnego uczenia się (organizational learning) jest konsekwencją poszukiwania nowych możliwości uzyskiwania przewagi konkurencyjnej na bazie wiedzy posiadanej przez organizacje i ich pracowników. Wiedza spersonalizowana pozyskiwana jest w procesie uczenia się pracowników, którzy, wykorzystując tę wiedzę w praktyce, prowadzą do uczenia się w wymiarze całej organizacji, a także do wspólnego uczenia się organizacji z jej interesariuszami. Organizacyjne uczenie się zaliczane jest zatem do kluczowych czynników rozwoju organizacji i jej pracowników, w tym również ich zatrudnialności. Rozwój zatrudnialności, pojmowanej również jako potencjał kariery, może przynieść korzyści zarówno danemu pracownikowi, jak i organizacji, w której jest zatrudniony (Marzec, 2016, s. 93-94; Raemdonck i in., 2015, s. 167-173; Van der Heijden i in., 2016, s. 7-11; Wiśniewska, 2017, s. 107-109). W związku z niewystarczającym rozpoznaniem w wyniku badań empirycznych relacji między organizacyjnym uczeniem się a zatrudnialnością jako cel niniejszego artykułu przyjęto określenie poziomu świadomości ankietowanych pracowników w zakresie znaczenia organizacyjnego uczenia się w procesie rozwoju zatrudnialności. $\mathrm{W}$ artykule podjęto próbę odpowiedzi na pytanie badawcze: Jaki jest poziom świadomości ankietowanych pracowników w zakresie znaczenia organizacyjnego uczenie się w rozwijaniu zatrudnialności? Na potrzeby artykułu dokonano przeglądu literatury przedmiotu oraz przeprowadzono analizę podjętego problemu badawczego, w której zastosowano metodę opisową. Zrealizowano również badania empiryczne oraz dokonano ich analizy z wykorzystaniem pakietu $I B M$ Predictive Solution 5. Wskazano także ograniczenia przeprowadzonych badań oraz kierunki dalszych badań w omawianym obszarze ${ }^{1}$.

\section{Istota organizacyjnego uczenia się}

K onceptualizacja i popularyzacja idei organizacyjnego uczenia się dokonała się przede wszystkim na podstawie publikacji takich autorów, jak P.M. Senge
Przegląd Organizacji, Nr 7(966), 2020, s. 20-27

www.przegladorganizacji.pl

( ) Towarzystwo Naukowe Organizacji i Kierownictwa (TNOiK)
(1990) czy Ch. Argyris i D.A. Schön (1996). Organizacyjne uczenie się jest różnorodnie definiowane. Do powszechnie cytowanych należy definicja sformułowana przez G. Probsta i innych (2002, s. 35). W ujęciu tych autorów jest to „proces, na który składają się zmiany w obrębie zasobów wiedzy, tworzenie wspólnych wzorców działań oraz wzrost organizacyjnych kompetencji służących bieżącej działalności i rozwiązywaniu problemów”.

Studia literatury przedmiotu wskazują, że organizacyjne uczenie się ma istotne znaczenie nie tylko dla sprawnego funkcjonowania danej organizacji, ale także dla rozpoznawania i antycypowania trendów rynkowych. Jest to szczególnie istotne w warunkach gospodarki opartej na wiedzy, w której wiedza staje się kluczowym źródłem przewagi konkurencyjnej organizacji na rynku.

Organizacyjne uczenie się można analizować na poszczególnych poziomach, na których proces ten zachodzi. Wyróżnia się następujące poziomy (Mikuła, 2002, s. 16-17; Sysko-Romańczuk i in., 2007, s. 7-8; Zgrzywa-Ziemak, 2009, s. 18-19; Chou, Ramser, 2019, s. 132-145; Morland i in., 2019, s. 78-96):

1. Pracownika - obejmuje procesy zachodzące w umysłach zatrudnionych, w wyniku których generowana i modyfikowana jest wiedza indywidualna związana z pracą $\mathrm{w}$ danej organizacji (wiedza ta determinuje wykonywanie zadań zawodowych przez poszczególnych pracowników). Wynikiem uczenia się na tym poziomie jest pogłębienie przez pracowników wiedzy, którą powinni wykorzystywać zarówno dla własnego rozwoju zawodowego, jak i rozwoju organizacji.

2. Zespołu - odnosi się do procesów będących efektem interakcji zachodzących pomiędzy pracownikami tworzącymi dany zespół. Procesy te zorientowane są na grupowe rozwiązywanie problemów i podejmowanie decyzji, stanowiących podstawę późniejszego wspólnego działania. Wynik uczenia się na tym poziomie to wspólna wiedza oraz sposób postrzegania problemów, a także często powstanie nowej wiedzy, odmiennej od tej będącej w posiadaniu poszczególnych członków zespołu.

3. Organizacji - dotyczy zmian zachodzących w takich elementach, jak: struktura organizacyjna, strategia działania czy kultura organizacyjna. Wy- 
nik uczenia się na tym poziomie to zinstytucjonalizowana wiedza organizacji, utrwalona $\mathrm{w}$ ramach wyżej wymienionych elementów, które powinny tworzyć spójną całość, umożliwiając sprawne funkcjonowanie organizacji i dostosowywanie jej do wymagań otoczenia.

4. Otoczenia - uczenie się na tym poziomie odbywa się przy współpracy z interesariuszami organizacji funkcjonującymi w jej otoczeniu. Może mieć ono charakter sformalizowany, np. przyjmując formę aliansów strategicznych dotyczących wspólnego rozwijania wiedzy w ramach działalności badawczo-rozwojowej, jak również nieformalny, np. w postaci wymiany poglądów pomiędzy pracownikami różnych organizacji na forach internetowych. Warto podkreślić, że proces ten przynosi podmiotom w nim uczestniczącym obopólne korzyści².

W literaturze przedmiotu wskazuje się również na trzy kluczowe subprocesy (typy) organizacyjnego uczenia się: tradycyjny (edukacyjny), empiryczny i cybernetyczny (Mikuła, 2005a, s. 11). Zasadniczą funkcją uczenia się $\mathrm{w}$ tradycyjnej postaci jest łączenie posiadanej wiedzy (głównie spersonalizowanej) z tą pozyskiwaną $\mathrm{z}$ otoczenia (przede wszystkim skodyfikowaną). Na wiedzy zdobytej w ramach edukacji w tradycyjnych formach bazuje empiryczne uczenie się. Ten subproces organizacyjnego uczenia się umożliwia weryfikację w praktyce posiadanej wiedzy i jej poszerzanie przykładowo poprzez eksperymentowanie. $Z$ kolei uczenie cybernetyczne opiera się na wiedzy zdobytej zarówno na podstawie tradycyjnego, jak i empirycznego uczenia się. Koncentruje się ono na tworzeniu i aktualizowaniu wiedzy, a także na doskonaleniu organizacyjnego uczenia się - uczeniu się jak uczyć się. W procesie tym ważne jest stworzenie mechanizmu zapobiegającego utracie przez organizację posiadanej wiedzy (Mikuła, 2005a, s. 11-12).

Wyodrębnienie poszczególnych poziomów i subprocesów organizacyjnego uczenia się pozwala na lepsze zrozumienie tego złożonego procesu. Ponadto umożliwia analizowanie organizacyjnego uczenia się w mniejszych wymiarach, które są determinowane przez zróżnicowane czynniki. Warto pokreślić, że poszczególne wymiary organizacyjnego uczenia się wzajemnie na siebie oddziałują i decydują o powodzeniu całości organizacyjnego uczenia się.

\section{Organizacyjne uczenie się a zatrudnialność}

$\mathbf{P}$ roblematyka zatrudnialności analizowana jest zarówno w zagranicznej, jak i polskiej literaturze przedmiotu. Mimo że termin employability po raz pierwszy został użyty na początku XX wieku przez W.H. Beveridge’a (1909, s. 215-216) i został rozpowszechniony w latach dziewięćdziesiątych, to w XXI wieku zagadnienie zatrudnialności jest przedmiotem licznych opracowań i analiz (Bennett i in., 2020; Froehlich i in., 2019; Herbert i in., 2020; Marzec, 2015; Paszkowicz, 2018; Pawłowska, 2017; Tentama i in., 2019; Wiśniewska, 2020).
W literaturze przedmiotu istnieją różne definicje i interpretacje pojęcia zatrudnialność. W ujęciu A. De Gripa i innych (2004, s. 220) zatrudnialność oznacza zdolność i gotowość pracowników do zachowania swojej atrakcyjności na rynku pracy (czynniki podażowe) poprzez antycypowanie zmian zachodzących w środowisku pracy oraz w zakresie zadań zawodowych, a także reagowanie na nie (czynniki popytowe), wspomaganą poprzez oferowane przez daną organizację instrumenty rozwoju zasobów ludzkich. Co istotne, interpretacja ta akcentuje wspólną odpowiedzialność za poziom zatrudnialności samych pracowników oraz pracodawców. Podkreśla także znaczenie wykorzystywanych przez organizacje narzędzi rozwoju zasobów ludzkich ${ }^{3}$.

W literaturze przedmiotu wskazuje się, że na poziom zatrudnialności pracowników oddziałuje środowisko pracy, a także ranga uczenia się i rozwoju w miejscu pracy. Uczenie się determinowane jest przez klimat uczenia się w organizacji, który warunkuje postawy, zachowania i motywację niezbędne do rozwijania zatrudnialności (Marzec, 2015, s. 93-97). Podkreśla się także, że stwarzanie możliwości uczenia się w miejscu pracy sprzyja wzmacnianiu zatrudnialności pracowników w długiej perspektywie (Opengart, Short, 2002, s. 225-227). Co istotne, wśród czynników związanych z karierą zawodową wpływających na zatrudnialność pracowników wymieniane jest uczenie się przez całe życie (Nauta i in., 2009, s. 235). Rezultaty analizy dotyczącej menedżerów również potwierdzają pozytywny wpływ uczenia się przez całe życie na poziom ich zatrudnialności (Sparrhoff, 2012, s. 3354-3355).

Wyniki badań przeprowadzonych wśród pracowników administracyjnych wyższych uczelni pozwoliły na stwierdzenie, że poziom ich zatrudnialności zależy zarówno od formalnego, jak i nieformalnego uczenia się. W związku $\mathrm{z}$ tym istotne jest stwarzanie możliwości uczenia się nie tylko w ramach sformalizowanych programów, ale także kreowanie nieformalnych możliwości uczenia się (Van der Heijden i in., 2009, s. 20, 32-33).

Warto zaznaczyć, że w celu zwiększenia poziomu zatrudnialności pracowników, wypracowane przez daną organizację rozwiązania w zakresie uczenia się powinny dotyczyć rozwijania zarówno miękkich kompetencji (związanych z komunikacją, pracą zespołową, rozwiązywaniem problemów, podejmowaniem decyzji), jak i twardych kompetencji powiązanych z określoną branżą. Organizacje wdrażające rozwiązania umożliwiające zatrudnionym efektywne uczenie się łatwiej pozyskują utalentowanych pracowników. Z kolei pracownicy, którzy rozumieją rolę uczenia się w zwiększaniu swojej zatrudnialności, zyskują szerokie grono potencjalnych pracodawców. Co istotne, za poziom zatrudnialności odpowiadają obie strony stosunku pracy, które czerpią obopólne korzyści ze wzrostu poziomu zatrudnialności pracowników w długim okresie (Clarke, Patrickson, 2008, s. 136). Ważne jest zatem podejmowanie działań ukierunkowanych na wzrost poziomu zatrudnialności zarówno przez pracowników (m.in. zaangażowanie $\mathrm{w}$ proces uczenia się), jak i organizację (m.in. implementacja rozwiązań umożliwiających pracownikom efektywne uczenie się). 


\section{Rozwiązania z zakresu organizacyjnego uczenia się wspierające rozwój zatrudnialności pracowników}

$\mathbf{N}$ a różnych poziomach organizacyjnego uczenia się (pracownika, zespołu i całej organizacji) można wykorzystać rozwiązania, które przyczyniają się do rozwoju zatrudnialności pracowników. Co warte podkreślenia, rozwiązania te mieszczą się w zakresie poszczególnych typów organizacyjnego uczenia się: tradycyjnego, empirycznego i cybernetycznego (tab. 1).

Przeprowadzone studia literatury przedmiotu wskazują, że wykorzystanie rozwiązań z zakresu organizacyjnego uczenia się, przedstawionych w tabeli 1, przyczynia się do rozwoju zatrudnialności pracowników danej organizacji. Warto podkreślić, że efektem uczenia się poszczególnych pracowników jest wzrost poziomu ich kompetencji. W kontekście kształtowania zatrudnialności istotne jest zarówno uczenie się poprzez udział w różnych formach kształcenia formalnego, pozaformalnego i nieformalnego, jak i uczenie się w wyniku działań praktycznych, również na własnych błędach. Obecnie kluczowe wydają się także nieformalne kontakty $\mathrm{z}$ interesariuszami organizacji oraz prowadzenie obserwacji pracy innych. Równie ważna staje się zdolność pracowników do krytycznej analizy i oceny własnych zachowań, a w konsekwencji do kwestionowania założeń pracy na danym stanowisku. Może to stanowić źródło innowacyjnych rozwiązań, możliwych do wdrożenia na poszczególnych stanowiskach pracy.

We współczesnych uwarunkowaniach rynkowych priorytetowego znaczenia nabiera także organizacyjne uczenie się na poziomie zespołu. Praca zespołowa sprzyja dzieleniu się wiedzą, pomysłami i doświadczeniami. Warto nadmienić, że w literaturze przedmiotu wśród korzyści wynikających z pracy zespołowej wskazuje się m.in. generowanie nowej wiedzy. Członkowie zespołów uczą się poprzez działania praktyczne dzięki partycypacji $\mathrm{w}$ realizacji różnorodnych projektów. Mają także możliwość uczenia się na podstawie błędów innych członków zespołu, co pomaga im uniknąć powielenia tych samych błędów. Warto podkreślić, że praca w ramach interdyscyplinarnych zespołów, dzięki efektom synergii, sprzyja wieloaspektowemu rozwojowi kompetencji. Co więcej, w ramach cybernetycznego uczenia się na poziomie zespołu możliwe jest również kwestionowanie dotychczasowych założeń funkcjonowania zespołu, co przyczynia się do kreowania nowych rozwiązań zaistniałych problemów oraz do zwiększenia zatrudnialności członków zespołu.

Warto również podkreślić, że w kontekście zwiększania zatrudnialności pracowników nieodzowne jest uczenie się na poziomie całej organizacji. W przypadku organizacji uczącej się wszyscy pracownicy powinni mieć świadomość, że organizacyjne uczenie się stanowi fundamentalną wartość, co oznacza, że należy uczyć się na wszystkich poziomach organizacji. Na poziomie całej organizacji istotne jest zatem kreowanie warunków do uczenia się zarówno przez poszczególnych pracowników, jak i zespoły, przykładowo poprzez takie rozwiązania, jak: firmowe biblioteki czy rozbudowane bazy wiedzy. Rozwiązania te czynią aktualną wiedzę łatwiej dostępną dla pracowników, co usprawnia proces uczenia się. Kadra kierownicza powinna uświadamiać swoim pracownikom przyjęte cele i motywować ich do skorelowania swoich ścieżek rozwoju i awansu $\mathrm{z}$ ustalonymi celami. Co więcej, aby uniknąć „ponownego odkrywania koła” przez poszczególnych pracowników czy zespoły, menedżerowie powinni propagować sprawdzone sposoby działania, w szczególności te z obszaru uczenia się.

Rozpatrując analizowaną kwestię, warto odnotować, że aby organizacja ucząca się mogła wspierać rozwój zatrudnialności swoich pracowników w dynamicznie zmieniających się uwarunkowaniach rynkowych, jakie można współcześnie obserwować, powinna permanentnie monitorować trendy rynkowe, potrzeby klientów czy poczynania konkurencji oraz na tej podstawie wdrażać zmiany, w szczególności w zakresie uczenia się. Powinna nieustannie starać się odpowiadać na pytanie: czego powinni uczyć się pracownicy i jak mają to robić? W sprawnym reagowaniu na potrzeby rynkowe pomocny okazać się może benchmarking funkcjonalny i zewnętrzny. Zgodnie z maksymą „kto stoi w miejscu, ten się cofa", nieodzownym elementem zarządzania organizacją uczącą się jest kwestionowanie założeń związanych $\mathrm{z}$ jej funkcjonowaniem, rutynowe przeprowadzanie rewizji procedur, wdrażanie innowacji, eksperymentowanie i podejmowanie ryzyka. W ciagłe doskonalenie organizacji powinni angażować się wszyscy pracownicy poprzez partycypację w zarządzaniu, zgłaszanie własnych pomysłów zmian czy prowadzenie działalności badawczo-rozwojowej. Poziomy konkurencyjności i innowacyjności, a także elastyczności organizacji uczącej się przekładają się bowiem na poziom zatrudnialności jej pracowników.

\section{Poziom świadomości pracowników w zakresie znaczenia organizacyjnego uczenia się w procesie rozwoju zatrudnialności na podstawie wyników badań własnych}

\section{Założenia metodyczne badań i próba badawcza}

$\mathbf{P}$ odstawowym celem badań było określenie poziomu świadomości ankietowanych pracowników w zakresie znaczenia organizacyjnego uczenia się $\mathrm{w}$ procesie rozwoju zatrudnialności. Do osiągnięcia założonego celu wykorzystano wtórne i pierwotne źródła informacji. $\mathrm{Na}$ początku przeprowadzono studia literatury przedmiotu, które posłużyły jako podstawa teoretyczna do analiz empirycznych. Następnie w okresie od września do grudnia 2019 r. zrealizowano badania empiryczne. Podmiot badań stanowili pracownicy różnych organizacji. Przedmiotem badań były rozwiązania $\mathrm{z}$ zakresu organizacyjnego uczenia się wspierające rozwój zatrudnialności pracowników. Badania przeprowadzono metodą badań sondażowych z wykorzystaniem techniki ankiety. Narzędzie badawcze 
stanowił internetowy kwestionariusz ankiety wspomagany komputerowo (ang. CAWI - Computer-Assisted Web Interview), zawierający głównie pytania zamknięte w formie tzw. pytań tabel lub pytań skal. Zastosowany w badaniach autorski kwestionariusz oceny poziomu świadomości pracowników w zakresie znaczenia organizacyjnego uczenia się w procesie rozwoju zatrudnialności charakteryzuje się wysoką rzetelnością. Wskaźnik Alfa-Cronbacha - współczynnik rzetelności kwestionariusza, rozumianej jako spójność wewnętrzna narzędzia, dla całego arkusza wynosi 0,971. Oznacza to, że wszystkie pozycje (itemy) skali ogólnej oraz poszczególnych podskal zostały uznane za rzetelne i włączone do kwestionariusza. Zasięg przestrzenny badań obejmował całą Polskę. Do analizy wyników badań wykorzystano pakiet IBM Predictive Solution 5.

Na potrzeby badań przyjęto, że zatrudnialność oznacza zdolność danej osoby do podjęcia, utrzymania i zmieniania zatrudnienia oraz rozwoju kariery zawodowej na wewnętrznym i zewnętrznym rynku pracy, wynikającą zarówno z czynników indywidualnych, jak i kontekstualnych. Organizacyjne uczenie się zdefiniowano z kolei jako

Tabela 1. Rozwiązania z zakresu organizacyjnego uczenia się mogące wspierać rozwój zatrudnialności pracowników

\begin{tabular}{|c|c|c|c|}
\hline \multirow{2}{*}{$\begin{array}{c}\text { Poziomy organizacyjnego } \\
\text { uczenia się }\end{array}$} & \multicolumn{3}{|c|}{ Typy organizacyjnego uczenia się } \\
\hline & Tradycyjny & Empiryczny & Cybernetyczny \\
\hline Pracownika & $\begin{array}{l}\text { - traktowanie uczenia się jako } \\
\text { procesu ciągłego, zaplanowanego } \\
\text { i świadomego, a nie } \\
\text { incydentalnego } \\
\text { - udział w różnych formach } \\
\text { kształcenia formalnego, } \\
\text { pozaformalnego i nieformalnego } \\
\text { - realizacja indywidualnych } \\
\text { planów rozwoju kompetencji, } \\
\text { m.in. poprzez samokształcenie } \\
\text { - pozyskiwanie wiedzy w wyniku } \\
\text { nieformalnych kontaktów } \\
\text { z interesariuszami organizacji, } \\
\text { m.in. klientami i dostawcami } \\
\text { - przekazywanie pracownikom } \\
\text { informacji zwrotnej o wynikach } \\
\text { ich pracy, a także informowanie } \\
\text { o planach i efektach } \\
\text { podejmowanych działań, co } \\
\text { ma umożliwić zatrudnionym } \\
\text { lepsze zrozumienie ich roli } \\
\text { w kontekście funkcjonowania } \\
\text { organizacji jako całości } \\
\text { - stosowanie nowoczesnych } \\
\text { technologii w procesie uczenia } \\
\text { się }\end{array}$ & $\begin{array}{l}\text { - zdobywanie doświadczeń } \\
\text { - } \text { r efekcie działań praktycznych na stanowiskach pracy } \\
\text { - uczenie się na podstawie } \\
\text { własnych błędów } \\
\text { - nauka poprzez interakcję } \\
\text { z pracownikami z innych } \\
\text { organizacji, a także } \\
\text { obserwowanie ich pracy } \\
\text { - partycypacja pracownicza } \\
\text { przejawiająca się m.in. } \\
\text { we współdecydowaniu } \\
\text { o realizowanych celach } \\
\text { i zadaniach oraz związanych } \\
\text { z nimi obszarach uczenia się } \\
\text { - podejmowanie własnych } \\
\text { inicjatyw w zakresie uczenia się } \\
\text { - wykorzystywanie studiów } \\
\text { przypadku w procesie uczenia się }\end{array}$ & $\begin{array}{l}\text { - krytyczna analiza i ocena } \\
\text { własnych zachowań, } \\
\text { a w konsekwencji } \\
\text { kwestionowanie założeń pracy na } \\
\text { danym stanowisku } \\
\text { - indywidualne poznawanie, } \\
\text { analizowanie i ocenianie założeń } \\
\text { dotyczących funkcjonowania } \\
\text { organizacji } \\
\text { - transfer informacji } \\
\text { napływających z otoczenia do } \\
\text { baz wiedzy organizacji } \\
\text { - praca nad własnymi projektami } \\
\text { - nagradzanie inicjatyw } \\
\text { pracowniczych } \\
\text { - budowanie systemu } \\
\text { motywacyjnego (obejmującego } \\
\text { instrumenty finansowe } \\
\text { i niefinansowe), przyczyniającego } \\
\text { się do wzrostu zaangażowania } \\
\text { pracowników w podnoszenie } \\
\text { kompetencji i realizację celów } \\
\text { organizacji }\end{array}$ \\
\hline Zespołu & $\begin{array}{l}\text { - zespołowe uczenie się, m.in. } \\
\text { poprzez wymianę wiedzy } \\
\text { i doświadczeń w ramach zespołu } \\
\text { - treningi pracy zespołowej } \\
\text { mające na celu integrację, rozwój } \\
\text { umiejętności pracy w grupie } \\
\text { i usprawnienie komunikacji } \\
\text { - podejmowanie przez } \\
\text { menedżerów w czasie spotkań } \\
\text { z podlegającymi im zespołami } \\
\text { problematyki funkcjonowania } \\
\text { całej organizacji i wpływu, } \\
\text { jaki wywiera na nią otoczenie, } \\
\text { a nieograniczanie się jedynie do } \\
\text { rozliczania zespołów z realizacji } \\
\text { przydzielonych im zadań } \\
\text { - stwarzanie możliwości } \\
\text { swobodnej wymiany poglądów } \\
\text { w ramach nieformalnych } \\
\text { interakcji pomiędzy członkami } \\
\text { poszczególnych zespołów } \\
\text { - porównywanie się z innymi } \\
\text { zespołami }\end{array}$ & $\begin{array}{l}\text { - nabywanie doświadczeń } \\
\text { w wyniku wykonywanej pracy } \\
\text { zespołowej } \\
\text { - uczenie się na bazie doświadczeń } \\
\text { innych, m.in. dzięki relacjom } \\
\text { z klientami, kooperantami } \\
\text { czy przedstawicielami } \\
\text { konkurencyjnych podmiotów } \\
\text { oraz dzięki wykorzystaniu } \\
\text { benchmarkingu wewnętrznego } \\
\text { - uczenie się poprzez analizę pracy } \\
\text { innych zespołów } \\
\text { - uczenie się na błędach } \\
\text { popełnionych przez innych, } \\
\text { m.in. poprzez ich analizę, } \\
\text { diagnozę ich przyczyn oraz } \\
\text { wskazywanie działań, które mogą } \\
\text { przyczynić się do uniknięcia } \\
\text { podobnych błędów w przyszłości } \\
\text { - ysoki stopień wymiany } \\
\text { wiedzy i doświadczeń wewnątrz } \\
\text { interdyscyplinarnych zespołów, } \\
\text { co pozwala na korzystanie } \\
\text { z własnych i cudzych } \\
\text { doświadczeń }\end{array}$ & $\begin{array}{l}\text { - } \text { analiza wydarzeń krytycznych } \\
\text { podstawionowanie załoźrych na nespół } \\
\text { dotychczas funkcjonował } \\
\text { - zespołowa ocena założeń } \\
\text { poszczególnych członków grupy } \\
\text { i ich modyfikacja } \\
\text { - wyjaśnianie i doskonalenie wizji } \\
\text { przyszłości } \\
\text { - generowanie wielu } \\
\text { innowacyjnych pomysłów } \\
\text { przy użyciu technik twórczego } \\
\text { rozwiązywania problemów } \\
\text { - praca zespołowa zogniskowana } \\
\text { wokół autorskich rozwiązań } \\
\text { - kreowanie klimatu } \\
\text { organizacyjnego sprzyjającego } \\
\text { konstruktywnej wymianie } \\
\text { poglądów i wspólnemu } \\
\text { wypracowywaniu innowacyjnych } \\
\text { rozwiązań }\end{array}$ \\
\hline
\end{tabular}




\begin{tabular}{|c|c|c|c|}
\hline \multirow{2}{*}{$\begin{array}{l}\text { Poziomy organizacyjnego } \\
\text { uczenia się }\end{array}$} & \multicolumn{3}{|c|}{ Typy organizacyjnego uczenia się } \\
\hline & Tradycyjny & Empiryczny & Cybernetyczny \\
\hline Organizacji & $\begin{array}{l}\text { - systematyczna lektura publikacji } \\
\text { związanych z profilem } \\
\text { działalności organizacji oraz } \\
\text { gromadzenie informacji, które } \\
\text { mogą zostać wykorzystane } \\
\text { w przyszłości } \\
\text { - określanie kierunków rozwoju } \\
\text { organizacji, a następnie } \\
\text { zapoznawanie z nimi } \\
\text { pracowników } \\
\text { - zarządzanie procesem } \\
\text { systematycznego szkolenia } \\
\text { w odpowiedzi na potrzeby } \\
\text { organizacji } \\
\text { - zwiększanie świadomości co } \\
\text { do konieczności uczenia się } \\
\text { na wszystkich poziomach } \\
\text { organizacji } \\
\text { - upowszechnianie różnych metod } \\
\text { uczenia się } \\
\text { - popularyzowanie ustawicznego } \\
\text { organizacyjnego uczenia się } \\
\text { jako podstawowej wartości } \\
\text { organizacji } \\
\text { - kształtowanie warunków do } \\
\text { uczenia się pracowników, } \\
\text { przede wszystkim zespołowego, } \\
\text { np. poprzez udostępnianie } \\
\text { pracownikom firmowych } \\
\text { bibliotek czy baz wiedzy }\end{array}$ & $\begin{array}{l}\text { - zastosowanie benchmarkingu } \\
\text { funkcjonalnego i zewnętrznego } \\
\text { w celu optymalizacji procesów } \\
\text { uczenia się zachodzących } \\
\text { w organizacji } \\
\text { - rozpoznawanie potrzeb klientów } \\
\text { i kreowanie w odpowiedzi } \\
\text { na nie ewolucyjnych zmian } \\
\text { w organizacji, również w zakresie } \\
\text { organizacyjnego uczenia się } \\
\text { - analiza trendów rozwojowych } \\
\text { obserwowanych zjawisk } \\
\text { i dostosowywanie do nich } \\
\text { kierunków uczenia się }\end{array}$ & $\begin{array}{l}\text { - nieustanne pozyskiwanie } \\
\text { informacji, ich selekcjonowanie, } \\
\text { klasyfikowanie i gromadzenie } \\
\text { w bazie wiedzy, co umożliwia } \\
\text { ich sprawne rozpowszechnianie } \\
\text { w organizacji (na ich podstawie } \\
\text { pracownicy mogą uczyć się) } \\
\text { - kwestionowanie założeń } \\
\text { związanych z funkcjonowaniem } \\
\text { organizacji, zwłaszcza tych } \\
\text { dotyczących jej misji, wizji } \\
\text { i strategii } \\
\text { - korzystanie z usług zewnętrznych } \\
\text { ekspertów } \\
\text { - gotowość do eksperymentowania } \\
\text { i odpowiedzialnego } \\
\text { podejmowania ryzyka } \\
\text { - dążenie do wzrostu } \\
\text { innowacyjności organizacji } \\
\text { oraz stosowanie innowacyjnych } \\
\text { rozwiązań w procesie uczenia się } \\
\text { - kreowanie warunków } \\
\text { umożliwiających pełne } \\
\text { wykorzystanie kapitału ludzkiego } \\
\text { organizacji } \\
\text { - zachęcanie pracowników do } \\
\text { zgłaszania i wprowadzania } \\
\text { usprawnień }\end{array}$ \\
\hline
\end{tabular}

Źródło: opracowanie własne na podstawie: Mikuła, 2005b, s. 88-90; Czekaj i in., 2007, s. 16-17; Rudawska, 2008, s. 241-244; Chou, Ramser, 2019, s. 132-145; Morland i in., 2019, s. 78-96

proces pozyskiwania, generowania, rozwijania i wykorzystywania wiedzy przez pracowników w odpowiedzi na misję i cele organizacji oraz wyzwania rynku (Wiśniewska, 2020, s. 62-63). Przyjęte definicje zostały zamieszczone w zaproszeniu do badań stanowiącym integralną część kwestionariusza ankiety.

Dobór próby badawczej miał charakter przypadkowy. W badaniach wzięło udział 251 osób, w tym 50 mężczyzn i 201 kobiet, co stanowiło odpowiednio $19,9 \%$ oraz $80,1 \%$ badanej populacji. Najmłodszy respondent miał 18 lat, a najstarszy 59 lat. Staż pracy badanych wynosił od 1 roku do 40 lat. Osoby ankietowane legitymowały się różnym poziomem wykształcenia. Najwięcej z nich miało wykształcenie licencjackie (24,7\%), średnie ogólnokształcące $(23,5 \%)$ i wyższe - magisterskie $(21,5 \%)$. Respondenci z wykształceniem średnim technicznym stanowili 19,5\% ogółu. Najmniej osób badanych reprezentowało następujące poziomy wykształcenia: policealne $(4,8 \%)$, inżynierskie $(1,6 \%)$, zasadnicze zawodowe $(1,6 \%)$, podstawowe $(1,6 \%)$ i wyższe - doktoranckie $(1,2 \%)$. Uczestnicy badań byli zatrudnieni w przedsiębiorstwach o różnej wielkości. Najwięcej ankietowanych było zatrudnionych w dużych $(31,9 \%)$ i mikroprzedsiębiorstwach $(28,7 \%)$. $\mathrm{Z}$ kolei $\mathrm{w}$ małych przedsiębiorstwach pracowało $21,9 \%$ respondentów. Najmniej licznie były reprezentowane średnie przedsiębiorstwa, w których było zatrudnionych 17,5\% badanych. Zdecydowana większość respondentów
$(57,4 \%)$ pracowała w organizacjach o profilu usługowym, $26,7 \%$ w organizacjach o profilu przemysłowym, a 15,9\% $\mathrm{w}$ organizacjach o profilu przemysłowo-usługowym. Ze względu na edytorskie ograniczenia w niniejszej publikacji przytoczono jedynie wybrane wyniki zrealizowanych badań.

\section{Wyniki badań}

W ramach przeprowadzonych badań empirycznych poproszono respondentów o ocenę ich poziomu świadomości w zakresie znaczenia organizacyjnego uczenia się $\mathrm{w}$ procesie rozwoju zatrudnialności. $\mathrm{W}$ badaniach zastosowano skalę Likerta $\mathrm{z}$ następującymi wariantami odpowiedzi: 0 - dane rozwiązanie nie jest stosowane, 1 - bardzo niskie znaczenie, 2 - niskie znaczenie, 3 - raczej niskie znaczenie, 4 - średnie znaczenie, 5 - raczej wysokie znaczenie, 6 - wysokie znaczenie, 7 - bardzo wysokie znaczenie. Badani ocenili swój poziom świadomości w zakresie znaczenia organizacyjnego uczenia się dla rozwoju własnej zatrudnialności średnio (M) na poziomie 4,9 przy odchyleniu standardowym (SD) równym 1,12 . Odnosząc się do poszczególnych poziomów organizacyjnego uczenia się, można stwierdzić, że największe znaczenie w kontekście rozwoju zatrudnialności ma poziom pracownika $(\mathrm{M}=5,22, \mathrm{SD}=1,42)$, następnie poziom organizacji $(M=5,06, S D=1,42)$, a $\mathrm{w}$ dalszej kolejności poziom zespołu $(\mathrm{M}=5,04, \mathrm{SD}=1,41)$. $\mathrm{Z}$ kolei 
Tabela 2. Wyniki oceny kluczowych rozwiązań z zakresu organizacyjnego uczenia się wspierających rozwój zatrudnialności pracowników

\begin{tabular}{|c|c|c|}
\hline Wyszczególnienie & Średnia (M) & $\begin{array}{l}\text { Odchylenie } \\
\text { standardowe (SD) }\end{array}$ \\
\hline \multicolumn{3}{|l|}{ Poziom pracownika } \\
\hline Uczenie się na podstawie własnych błędów & 5,48 & 1,42 \\
\hline Obserwowanie pracy innych pracowników & 5,28 & 1,38 \\
\hline Przekazywanie pracownikom informacji zwrotnej o wynikach ich pracy (feedback) & 5,14 & 1,51 \\
\hline Samokształcenie & 5,09 & 1,55 \\
\hline $\begin{array}{l}\text { System motywacyjny (obejmujący instrumenty finansowe i niefinansowe) przyczyniający } \\
\text { się do wzrostu zaangażowania w podnoszenie kompetencji }\end{array}$ & 5,07 & 1,78 \\
\hline \multicolumn{3}{|l|}{ Poziom zespołu } \\
\hline $\begin{array}{l}\text { Swobodna wymiana poglądów w ramach nieformalnych interakcji pomiędzy członkami } \\
\text { zespołu }\end{array}$ & 5,15 & 1,41 \\
\hline Zespołowe uczenie się (m.in. poprzez wymianę wiedzy i doświadczeń w ramach zespołu) & 5,11 & 1,62 \\
\hline $\begin{array}{l}\text { Zespołowe uczenie się na bazie doświadczeń innych (m.in. dzięki relacjom z klientami, } \\
\text { dostawcami) }\end{array}$ & 5,02 & 1,49 \\
\hline $\begin{array}{l}\text { Wymiana wiedzy i doświadczeń wewnątrz interdyscyplinarnych zespołów (co pozwala na } \\
\text { korzystanie z własnych i cudzych doświadczeń) }\end{array}$ & 4,97 & 1,45 \\
\hline $\begin{array}{l}\text { Zespołowa analiza wydarzeń krytycznych (tkwiących w otoczeniu czynników, które mogą } \\
\text { utrudnić realizację celu i zadań) }\end{array}$ & 4,90 & 1,48 \\
\hline \multicolumn{3}{|l|}{ Poziom organizacji } \\
\hline Zachęcanie pracowników do zgłaszania i wprowadzania usprawnień & 5,08 & 1,65 \\
\hline Stosowanie innowacyjnych rozwiązań w procesie uczenia się & 4,91 & 1,57 \\
\hline Korzystanie z usług zewnętrznych ekspertów & 4,77 & 1,61 \\
\hline Gotowość do eksperymentowania i odpowiedzialnego podejmowania ryzyka & 4,73 & 1,62 \\
\hline Upowszechnianie różnych metod uczenia się & 4,68 & 1,63 \\
\hline \multicolumn{3}{|l|}{ Poziom otoczenia } \\
\hline Wymiana poglądów na forach internetowych & 4,52 & 1,70 \\
\hline Alianse strategiczne & 4,29 & 1,48 \\
\hline
\end{tabular}

Źródto: opracowanie wtasne

najmniejsze znaczenie ma poziom otoczenia $(M=4,71$, $\mathrm{SD}=1,45)$. Szczegółowe wyniki oceny kluczowych, zdaniem respondentów, rozwiązań z zakresu organizacyjnego uczenia się sprzyjających rozwojowi ich zatrudnialności przedstawiono w tabeli 2.

W ramach oceny znaczenia poszczególnych rozwiązań z zakresu organizacyjnego uczenia się ukierunkowanych na zwiększanie zatrudnialności pracowników na poziomie pracownika najwyższe znaczenie przypisano takim rozwiązaniom, jak: uczenie się na podstawie własnych błędów $(M=5,48, S D=1,42)$, obserwowanie pracy innych pracowników $(M=5,28$, $\mathrm{SD}=1,38)$, przekazywanie pracownikom informacji zwrotnej o wynikach ich pracy - feedback $(M=5,14$, $\mathrm{SD}=1,51)$. Na poziomie zespołu zdiagnozowane rozwiązania o najwyższym znaczeniu to: swobodna wy- miana poglądów w ramach nieformalnych interakcji pomiędzy członkami zespołu $(\mathrm{M}=5,15, \mathrm{SD}=1,41)$, zespołowe uczenie się m.in. poprzez wymianę wiedzy i doświadczeń w ramach zespołu $(M=5,11, S D=1,62)$, zespołowe uczenie się na bazie doświadczeń innych, m.in. dzięki relacjom z klientami, dostawcami $(\mathrm{M}=5,02, \mathrm{SD}=1,49)$. Z kolei na poziomie organizacji respondenci kluczowe znaczenie przypisali następującym rozwiązaniom: zachęcanie pracowników do zgłaszania i wprowadzania usprawnień $(\mathrm{M}=5,08, \mathrm{SD}=$ $1,65)$, stosowanie innowacyjnych rozwiązań $\mathrm{w}$ procesie uczenia się $(\mathrm{M}=4,91, \mathrm{SD}=1,57)$, korzystanie $\mathrm{z}$ usług zewnętrznych ekspertów $(\mathrm{M}=4,77, \mathrm{SD}=1,61)$. W przypadku poziomu otoczenia największe znaczenie dla poziomu zatrudnialności ma wymiana poglądów na forach internetowych $(\mathrm{M}=4,52, \mathrm{SD}=1,70)$. 


\section{Podsumowanie}

W dobie dynamicznego wzrostu światowych zasobów wiedzy, intensyfikacji postępu technicznego czy skracania się cyklów życia innowacji, pracownicy, którzy nie potrafią szybko i skutecznie uczyć się, nie będą w stanie utrzymać poziomu swej zatrudnialności. Wydaje się, że współcześnie, aby zachować lub wzmocnić swoją pozycję na ewoluującym rynku pracy, trzeba uczyć się oduczać i uczyć się na nowo sposobów wykonywania swoich obowiązków zawodowych. Permanentne uczenie się zapobiega dezaktualizacji wiedzy i jest wprost koniecznością ze względu na liczne zmiany zachodzące w miejscu pracy i otoczeniu społeczno-gospodarczym.

$\mathrm{Na}$ poziom zatrudnialności pracowników może przekładać się model organizacji, w której aktualnie są zatrudnieni. Pożądanym w kontekście zachowywania i zwiększania poziomu zatrudnialności pracowników modelem organizacji jest organizacja ucząca się. Wykorzystywane są w niej liczne rozwiązania, które pomagają pracownikom skutecznie uczyć się, zarówno indywidualnie, jak i w ramach pracy zespołowej. Co istotne, w tego typu podmiotach uczenie się jest również umiejętnie wspierane na płaszczyźnie całej organizacji. Zdaniem autorów niniejszego artykułu, analizowane rozwiązania $\mathrm{z}$ zakresu tradycyjnego, empirycznego i cybernetycznego uczenia się stanowią determinantę rozwoju zatrudnialności pracowników na współczesnym rynku pracy.

Odnosząc się do postawionego pytania badawczego, na podstawie poczynionych studiów literaturowych i wyników przeprowadzonych badań empirycznych można stwierdzić, że poziom świadomości ankietowanych pracowników w zakresie znaczenia organizacyjnego uczenia się w procesie rozwoju zatrudnialności jest wysoki. W szczególności zależność ta jest widoczna na poziomie pracowniczym i organizacyjnym. Również poszczególne rozwiązania $\mathrm{z}$ zakresu organizacyjnego uczenia się wykorzystywane na czterech omawianych poziomach mają znaczenie w kontekście poziomu zatrudnialności pracowników. Uzasadniona wydaje się zatem popularyzacja rozwiązań z zakresu organizacyjnego uczenia się w praktyce gospodarczej. Dotyczy to w szczególności organizacji zainteresowanych rozwojem swoich pracowników wpływającym na poziom ich zatrudnialności.

Rozważania zawarte $\mathrm{w}$ niniejszym opracowaniu stanowią podstawę dalszych badań empirycznych realizowanych przez autorów, które dotyczą pogłębionej analizy możliwości zwiększania zatrudnialności pracowników organizacji poprzez zastosowanie rozwiązań wykorzystywanych w ramach wdrażania koncepcji organizacyjnego uczenia się na poszczególnych poziomach. Warto odnotować, że zrealizowane badania mają charakter idiograficzny, co oznacza, że na podstawie uzyskanych wyników nie można sformułować uogólnionych wniosków ze względu na brak zastosowania procedur losowania próby. Przedstawione wnioski dotyczą jedynie badanej populacji.

\author{
dr Sylwia Wiśniewska \\ Uniwersytet Ekonomiczny w Krakowie \\ Kolegium Nauk o Zarządzaniu i Jakości \\ ORCID: 0000-0003-4760-2634 \\ e-mail: sylwia.wisniewska@uek.krakow.pl
}

\section{dr Kamil Wiśniewski \\ Uniwersytet Jana Kochanowskiego w Kielcach \\ Wydział Prawa i Nauk Społecznych \\ ORCID: 0000-0002-4708-4163 \\ e-mail: kamil.wisniewski@ujk.edu.pl}

\section{Przypisy}

1) Projekt finansowany $w$ ramach programu Ministra Nauki i Szkolnictwa Wyższego pt. Regionalna Inicjatywa Doskonałości w latach 2019-2022 (nr projektu: 021/RID/2018/19, kwota dofinansowania: 11897 131,40 PLN).

2) W literaturze przedmiotu prezentowane są także inne poziomy lub płaszczyzny organizacyjnego uczenia się, np. single-loop learning, double-loop learning (Argyris, Schön, 1996).

3) Szerzej na temat pojęcia, wymiarów i determinant zatrudnialności pisze S. Wiśniewska (2015, s. 11-24).

\section{Bibliografia}

[1] Argyris Ch., Schön D.A. (1996), Organizational Learning II: Theory, Method and Practice, Addison-Wesley, Reading.

[2] Bennett D., Knight E., Rowley J. (2020), The Role of Hybrid Learning Spaces in Enhancing Higher Education Students' Employability, „British Journal of Educational Technology”, Vol. 51, No. 4, pp. 1188-1202.

[3] Beveridge W.H. (1909), Unemployment: A Problem of Industry, Longmans, Green, and co., London.

[4] Chou S.Y., Ramser C. (2019), A Multilevel Model of Organizational Learning: Incorporating Employee Spontaneous Workplace Behaviors, Leadership Capital and Knowledge Management, „The Learning Organization”, Vol. 26, No. 2, pp. 132-145.

[5] Clarke M., Patrickson M. (2008), The New Covenant of Employability, „Employee Relations”, Vol. 30, No. 2, pp. 121-141.

[6] Czekaj J., Ziębicki B., Kafel T., Walczak M., Teczke J. (2007), Koncepcja organizacyjnego uczenia się, [w:] J. Czekaj (red.), Metody organizacji i zarzadzania, Wydawnictwo Akademii Ekonomicznej w Krakowie, Kraków, s. 11-83.

[7] De Grip A., Van Loo J., Sanders J. (2004), The Industry Employability Index: Taking Account of Supply and Demand Characteristics, „International Labour Review”, Vol. 143, No. 3, pp. 211-233.

[8] Froehlich D.E., Segers M., Beausaert S., Kremer M. (2019), On the Relation between Task-Variety, Social Informal Learning, and Employability, „Vocations and Learning”, No. 12, pp. 113-127.

[9] Herbert I.P., Rothwell A.T., Glover J.L., Lambert S.A. (2020), Graduate Employability, Employment Prospects and Work-readiness in the Changing Field of Professional Work, "The International Journal of Management Education", Vol. 18, No. 2, p. 100378. 
[10] Marzec I. (2015), Uwarunkowania rozwoju zatrudnialności pracowników w organizacji, Wydawnictwo Uniwersytetu Ekonomicznego w Katowicach, Katowice.

[11] Marzec I. (2016), Konsekwencje rozwoju zatrudnialności pracowników w organizacjach publicznych: Szansa czy zagrożenie? „Prace Naukowe Uniwersytetu Ekonomicznego we Wrocławiu", Nr 419, s. 87-94.

[12] Mikuła B. (2002), Modele przedsiębiorstwa przyszłości, [w:] B. Mikuła, A. Pietruszka-Ortyl, A. Potocki, Zarzqdzanie przedsiębiorstwem XXI wieku: Wybrane koncepcje i metody, Difin, Warszawa, s. 9-19.

[13] Mikuła B. (2005a), Procesy organizacyjnego uczenia się $w$ aliansie strategicznym, „Przegląd Organizacji”, $\mathrm{Nr}$, s. 9-12.

[14] Mikuła B. (2005b), Organizacyjne uczenie się, [w:] K. Perechuda (red.), Zarządzanie wiedza w przedsiębiorstwie, Wydawnictwo Naukowe PWN, Warszawa, s. 85-93.

[15] Morland K.V., Breslin D., Stevenson F. (2019), Development of a Multi-level Learning Framework, „The Learning Organization", Vol. 26, No. 1, pp. 78-96.

[16] Nauta A., Van Vianen A., Van der Heijden B., Van Dam K., Willemsen M. (2009), Understanding the Factors that Promote Employability Orientation: The Impact of Employability Culture, Career Satisfaction, and Role Breadth Self-Efficacy, „Journal of Occupational and Organizational Psychology", No. 82, pp. 233-251.

[17] Opengart R., Short D.C. (2002), Free Agent Learners: The New Career Model and its Impact on Human Resource Development, „International Journal of Lifelong Education”, Vol. 21, No. 3, pp. 220-233.

[18] Paszkowicz M.A. (2018), Zatrudnialność osób z niepetnosprawnościami w świetle capability approach, Oficyna Wydawnicza Uniwersytetu Zielonogórskiego, Zielona Góra.

[19] Pawłowska A. (2017), Zatrudnialność pracobiorcy $w$ elastycznym zarządzaniu ludźmi, PWE, Warszawa.

[20] Probst G., Raub S., Romhardt K. (2002), Zarzadzanie wiedza w organizacji, Oficyna Ekonomiczna, Kraków.

[21] Raemdonck I., Beausaert S., Fröhlich D., Kochoian N., Meurant C. (2015), Aging Workers' Learning and Employability, [in:] P. Bal, D. Kooij, D. Rousseau (eds.), Aging Workers and the Employee-Employer Relationship, Springer, Cham, pp. 163-184.

[22] Rudawska A. (2008), Zdolność przedsiębiorstw do indywidualnego uczenia się a wyniki ich działalności, [w:] A. Glińska-Neweś (red.), Zarządzanie organizacjami w gospodarce opartej na wiedzy. Zasobowe podstawy funkcjonowania i rozwoju organizacji, Wyd. Dom Organizatora, Toruń, s. 241-244.

[23] Senge P.M. (1990), The Fifth Discipline: The Art and Practice of The Learning Organization, Doubleday/Currency, New York.

[24] Sysko-Romańczuk S., Lozano Platonoff A., Rudawska A. (2007), Koncepcja organizacyjnego uczenia się - podstawowe perspektywy badawcze, „Ekonomika i Organizacja Przedsiębiorstwa”, Nr 2, s. 3-12.

[25] Sparrhoff G.R. (2012), Learning for Employability: Managers' Self-governance and Learning in Organizational Practices, „Procedia - Social and Behavioral Sciences”, No. 46, pp. 3350-3355.
[26] Tentama F., Subardjo, Abdillah M.H. (2019), Motivation to Learn and Social Support Determine Employability among Vocational High School Students, „International Journal of Evaluation and Research in Education", Vol. 8, No. 2, pp. 237-242.

[27] Van der Heijden B., Boon J., Van der Klink M., Meijs E. (2009), Employability Enhancement through Formal and Informal Learning: An Empirical Study among Dutch Non-academic University Staff Members, „International Journal of Training and Development", Vol. 13, No. 1, pp. 19-37.

[28] Van der Heijden B.I.J.M., Gorgievski M.J., De Lange A.H. (2016), Learning at the Workplace and Sustainable Employability: A Multi-source Model Moderated by Age, „European Journal of Work and Organizational Psychology", Vol. 25, No. 1, pp. 13-30.

[29] Wiśniewska S. (2020), Organizational Learning and Employability in Enterprises: Preliminary Empirical Research Results, „Human Resource Management”, No. 3-4, pp. 61-73.

[30] Wiśniewska S. (2015), Zatrudnialność - pojęcie, wymia$r y$, determinanty, „Edukacja Ekonomistów i Menedżerów. Problemy, Innowacje, Projekty", Nr 1, s. 11-24.

[31] Wiśniewska S. (2017), Zarzadzanie różnorodnościa w rozwijaniu zatrudnialności pracowników $w$ organizacji, „Studia i Materiały. Miscellanea Oeconomicae”, T. 1, Nr 1, s. $107-114$.

[32] Zgrzywa-Ziemak A. (2009), Istota organizacyjnego uczenia się, [w:] A. Zgrzywa-Ziemak, R. Kamiński (red.), Rozwój zdolności uczenia się przedsiębiorstwa, Difin, Warszawa, s. 11-38.

\section{Organizational Learning as a Determinant of Worker Employability}

\section{Summary}

The aim of the article is to indicate the importance of organisational learning in developing the employability of employees. The study presents the essence of the concepts: organisational learning and employability. It also shows the relations between organisational learning and employability. Moreover, it analyses solutions in the field of traditional, empirical, and cybernetic learning that support development of worker employability. Importantly, it establishes that solutions in the field of traditional, empirical, and cybernetic learning are an important determinant of worker employability on the modern labour market. The study reviews the subject literature as well as discusses the results of surveys carried out among employees from Poland. It also analyses the research problem applying a descriptive method and IBM Predictive Solution 5.

\section{Keywords}

employability, organizational learning, competencies, knowledge 